\title{
コロナ放電によるオゾンの発生効率に及ぼす 電極形状の影響
}

\author{
正 員 前 園 一 郎 (徳山高専)
Effect of Electrode Configuration on Ozone Formation Efficiency in Corona Discharge
Ichiro Maezono, Member (Tokuyama College of Technology)

キーワード：オソ゚ン，発生効率，コロナ放電

オゾンは強い酸化力を有するのて，その酸化作用を 利用して殺菌, 隇菌, 脱臭, 脱色など, 幅広い工業分 野にその用途が開かれている。ことに余剩の $\mathrm{O}_{3}$ は分 解して ${ }_{2}$ になるので，二次公害のない物質としてそ の利用が注目されている。しかしながらコロナ放電に よるオゾンの生成はエネルギー効率が低く, 電気工ネ ルギーの 5〜11\%ほどしかオゾン生成に使われなかっ たため，我が国でも外国に括いてもオゾンの発生効率 を向上するための研究が活発に行われてきただ(1) (2)

本研究は，接地側の電極構造を変えることによって ストリーマコロナ放電路を変光, 放電空間領域を集束 することによってオゾンの発生効率を高めることがで きることを示した実験結果の報告である。

\section{1、赛験方法}

図 1 は本実験に用いた電極の構成図で,内径 5 $\mathrm{mm}$, 外径 $6 \mathrm{~mm}$ の中空電極で, 先端側面に厚さ 0.2 $\mathrm{mm}$, 高さ $1.5 \mathrm{~mm}$, 長さ $3 \mathrm{~mm}$ の薄い黄銅のフィン を 8 枚等間隔に設けた電極を陽極としているる

陰極は直径 $52 \mathrm{~mm} の$ 黄銅製近似ロゴスキー電極 (または直径 $20 \mathrm{~mm}$ の球電極) を用いる。これらの電 極を内径 $60 \mathrm{~mm}$, 外径 $68 \mathrm{~mm}$ の透明アクリル樹脂の パイプに封入固定し，陰極はマイクロアンメータ (YEW TYPE 2011, 内部抵抗 $0.88 \mathrm{k} \Omega$ ) を通して接 地している。混合ガス（酸素 $21 \%$ ，䇪素79\%）を $0.6 \mathrm{l} / \mathrm{min}$ で陰極側から陽極側へ流し，フィン付きの 中空電極に正極性直流高電圧を印加する。ガス排出口 屾大気開放とし，ガスの一部はオゾン濃度計 (Dylec, DY-1500）を通過後大気中へ排出している。印加電 圧は高压プローブ (IWATU, 入力抵抗約 1,000 $\mathrm{M} \Omega$, 分圧比 1,000：1）とディジタルマルチメータ
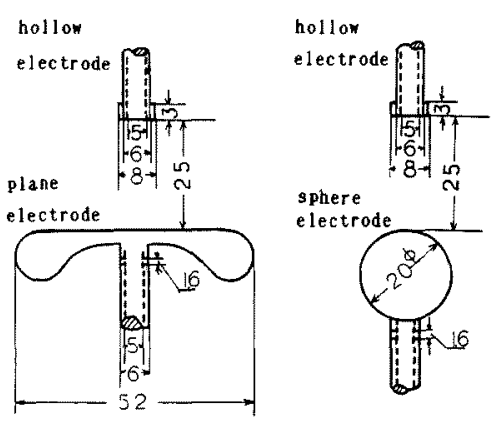

図 1 コロナ放電発生用電極の形状

Fig. 1. Configuration of electrodes for corona discharge.

(IWATU, VOAC 757) を用いて測定し, 電圧, 電 流，コロナ放電空間に消費される電力，オゾン濃度な どを測定し, 陰極形状の違いによるオゾン濃度の変化 を調べた。

\section{2. 実験結果ならびに考察}

图 2(a) は平板電極を陰極とした場合の放電の外観 で，極めて瀻細な線条のストリーマコロナを電極間に 均一に形成することができる。

一方，陰極を球とすると，放電の外観は（b)罒のよ うになり, 平板電極と比べて陰極側でストリーマコロ ナを集束させることができる。このことによりオゾン 発生量を増大させることができる。

図了は陰極に平板電極を用いた場合の放電電力とオ ゾン濃度の関係を示したもので，放電電力とオゾン濃 度はほほ比例し, 電極間距離の增大に対しては隇少し てくることがわかる。 


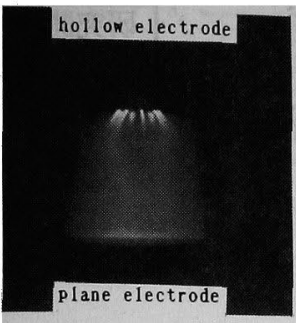

(a) 中空電極-平板電極間コ 口十放電の外観（電圧 $=25.4$ $\mathrm{kV}$, 電流 $=0.182 \mathrm{~mA}$, カス流 童 $=0.6 \mathrm{l} / \mathrm{min}$, 電極間距離= $25 \mathrm{~mm}$, 校り $=\mathrm{F} 1.4, *+\cdots$ タスピード $=1 / 2 s$ )

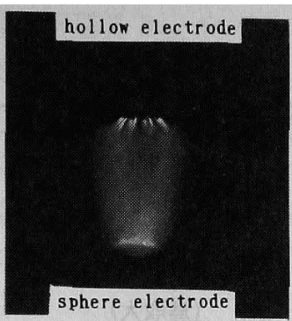

(b) 中空電極-球電極間コロナ 放電の外観 (電圧 $=27.8 \mathrm{kV}$, 電流 $=0.10 \mathrm{~mA}$, ガ ス流量 $=$ $0.6 \mathrm{l} / \mathrm{min}$, 電極間距 離 $=25$ $\mathrm{mm}$, 絞り $=$ F 1.4, シャッ夕 スピード $=1 / 2 \mathrm{~s}$ )

図 2

Fig. 2.

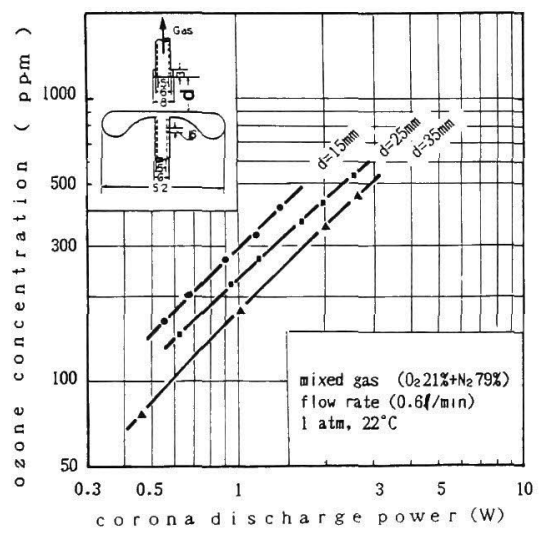

図 3 平板電極を陰極としたときの放電電力 とオゾン濃度特性

Fig. 3. Characteristics of ozone concentration versus corona discharge power in case using plane- electrode as negative polarity.

図 4 は球電極を陰極としたときの放電電力とオゾン 濃度を示したものである。いま, 電極間距離 $d=25$ $\mathrm{mm}$, 放電電力 $1 \mathrm{~W}$ のときを比較してみると, 平板 電極を用いた場合には約 $230 \mathrm{ppm}$ のオゾンが発生し, 球電極では約 $300 \mathrm{ppm}$ 発生しており, 約 $30 \%$ の効率 向上となっている。これはストリーマコロナを集束さ せたことによる効果と考えられ, 放電空間の電子密度 やオン密度が高くなることにより, 空気中の酸素分子

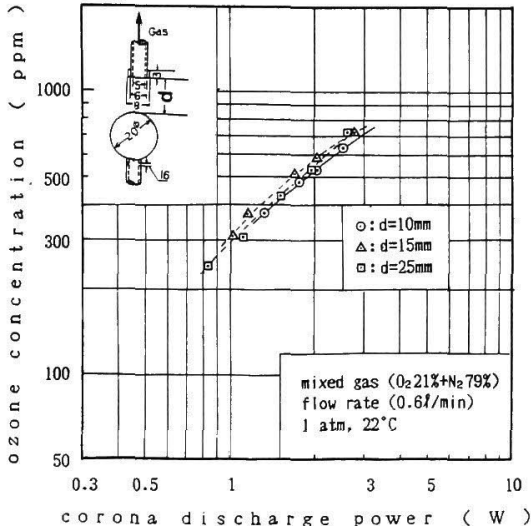

図 4 陰極に球電極を用いた場合の放電電力 とオゾン濃度特性

Fig. 4. Characteristics of ozone concentration versus corona discharge power in case using sphere electrode as negative polarity.

や窒素分子との衝突確率が増大したことによるものと 思われる。

(平成 2 年 12 月 19 日受付)

$$
\text { 文献 }
$$

（1）山部・高瀬，他：「空気原料を用いた大気圧グロー放電によ るオソン生成」, 電気学会研資, ED-90-103, 121 (平 2)

(2) S. Masuda, K. Akutsu, M. Kuroda, Y. Awatsu \& Y Shibuya : "A ceramic based ozonizer using high frequency discharge", IEEE Trans. Industr. Applic. 24, 223 (1988)

(3) 前園：「ガス処理用コロナ放電発生電極の構成方法につい て」, 電学諭 $\mathrm{C}, \mathbf{1 1 0}, 445$ (平 2-7)

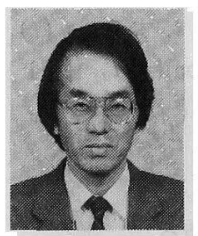

前 園 - 郎 (正員)

昭和 15 年 2 月 7 日生。 44 年 3 月 九州工業大学大学院修士課程電気工 学専攻修了。 51 年徳山高専機械電 気工学科講師, 53 年同助教授, 平 成元年同教授。その間, 文部省在外研究員 $(62$ 年 8 月〜 63 年 6 月，カナダ，アメリカ）などを経て現在 に至る。主として，オゾン生成などコロナ放電現象の 応用に関する研究に従事。IEEE会員。 